\title{
Axiological Evaluation as the Base of Knowledge and Cultural Research of Spanish and Uzbek Languages
}

\author{
Bakhronova Dilrabo Keldiyorovna, Abdullayeva Sokhibakhon Yakubovna
}

\begin{abstract}
Language and speech are the main factors in human life. Language is a spiritual wealth which connects all generations, preserves and saves cultural and scientific property created by humanity, furnishing them for the next generation. Developing mutual relations in various spheres among the nations of the world needs new scientific researches in modern spheres and the field of linguistics, such as culture-oriented linguistics, ethno linguistics. All nations in the world have their own national-cultural traditions and customs which is worth studying in order to have successful communication between nations and understanding them.
\end{abstract}

Keywords: Language and speech, axiological assessing, evaluation, traditions and customs, metaphor, anthromorph.

\section{INTRODUCTION}

"Language is a translator which interprets speaker's wishes for the listener» "Tarikh Al-Hind" (History of India) by Abu Rayhan Al-Biruni

Successful communication between nations much depends on how well they are familiar with the norms, traditions and customs of each other. There are particular ideas which reside in the nation formed as a result of the effect of social-historical situations that express a nation's mood, mentality and character, and are important in social-cultural development. In the XV century, a well-known Uzbek poet, Alisher Navoiy, whose work «Judgment of Two Languages» was published in English in 1962, spoke of the power of the word and the existence of peculiarities in the language of every nation:

So'z durrining tafovuti mundin dog'i beg'oyatroq va martabasi mundin ham benihoyatroqdur. Va bu so zning tanavvui taaqquldin nari va tasavvurdin tashqaridur. Agar mubolag 'asiz ijmol yuzidin qalam surulsa va ixtisor jonibidin raqam urulsa, etmish ikki nav' bila taqsim toparida, xud hech so 'z yo 'qturki, etmish ikki firqa kalomig 'a dalolat qilg 'ay; ammo ulcha tafsiliydur. Uldurkim, rub'i maskunning etti iqlimidin har iqlimda necha kishvar bor va har kishvarda necha shahar va qasaba va kent va har dashtda necha xayl-xayl sahronishin ulus va har tog'ning qo'llarida va qullalarida va har bahrning jazoyirida va savohilida ne tavoyif bor. Har jamoat alfozi o zgalaridin va har guruh iborati yonalaridin mutag 'ayyir va bir necha xususiyat bila

Revised Version Manuscript Received on 16 September, 2019.

* Correspondence Author

Bakhronova Dilrabo Keldiyorovna, PhD, Associate Professor at the Department of Languages of Academy of the Armed Forces of Uzbekistan mail: akaduz@umail.ru

Abdullayeva Sokhibakhon Yakubovna, $\mathrm{PhD}$, Associate Professor at the Department of Languages of Academy of the Armed Forces of Uzbekistan

mail: akaduz@umail.ru mutamayyizdurki, o'zgalarda yo 'qtur.(Ali-Shir Nava'I, «Muhakamat al-Lughatayn»).

What this quote briefly says is that the value of the word is much greater than the value of the pearl. There may well be, for instance, 72 types of a word spread all over the world, and they may have their own specific meaning. Nonetheless, there is a vast number of cities, towns and villages all over the world, each with its own language, and that language is specific to its own native people only. Their languages are not similar to other nation's languages (Ali-ShirNava'I, «Judgment of Two Languages» (Muhakamat al-Lughatayn)). Teaching foreign languages effectively has always been an important task, in addition to learning the communication behavior of people living in the area where the pertinent language is spoken, as well as studying the peculiarities of that language.

Nowadays, axiological assessment is actively used in reassessing traditions and customs, rehabilitating, preserving and transferring national traditions and customs for future generations, clarifying factors that change the new traditions and customs in particular people's minds, and solving existing problems in linguistics, philosophy and cultural studies (Mertens 2009, Harris and all. 2009) ${ }^{1}$.

An axiological approach is very important in culture-oriented linguistics, because culture is analyzed as the system of traditions and customs forming the program of human activity which is expressed in language. It can therefore be argued that culture-oriented linguistics is the expression of a concrete scientific system of knowledge about traditions and customs and the mechanisms of creating them. In this sense, the actions of humans are influenced by their traditions and customs.

Occasions on which traditions and customs are brought into play are divided into three necessary structural parts known as cognition: the subject (the "assessor"), the object (which "assesses") and the particular relationship between them (the "assessing"). One of the best presentations of the role of hierarchy may be found in the works of M. Sheler. His argument is that there exists a particular order in the world of traditions and customs, meaning that they are flexible in nature, one 'hierarchy' being 'higher' or 'lower' than others.

1 Mertens, Donna M. (2009). Transformative Research and Evaluation. The Guilford Press, New York. ISBN 978-1-59835-302-0; Harris, R., Holmes, H., \& Mertens, D. (2009). Research Ethics in Sign Language Communities. Sign Language Studies, 9(2), 104-131. Retrieved from http://www.jstor.org/stable/26190667

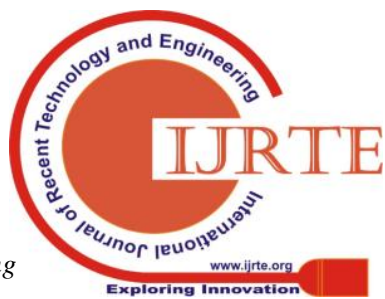


This hierarchy is a result of its division into two elements: assessed as "positive" and "negative", not related merely to "some traditions and customs we know".

As Mertens said, the transformative axiological assumption promotes the principles of respect, beneficence, and justice on several fronts [Mertens, 2009: 49].

A speaker's purpose is giving information to the listener, something which at the same time can exert an emotional influence on him or her. Very often the semantic content gives a clue to what is implied in the message. If we take as an example the words 'fox' (animal) and 'fox' (human), the difference between them is whether the speaker exerts emotional influence or not.

The first of these does not signal any particular aspect, where as the second one does. There is a common link between 'fox' and the word 'animal' from a semantic, denotative and signifying point of view. The word 'fox' is related to the word fox in the meaning of crafty, cunning. It is clear that the evaluation plays an important role here.

Axiology is it ethnical considerations include respect for cultural norms of interaction; beneficence is difined in terms of the promotion of human rights and increarse in social justice.

Also in the the research investigation of ethics that involve human participants are based on there principles that serve as evaluations of human actions: respect, beneficence, and justice $[105]^{2}$.

\section{RESEARCH METHODOLOGY AND RESULTS}

A human being, from the moment of birth, lives in close relation to Nature as part of his or her surroundings. In the past, ancient people studied and analysed events in Nature and the universe within the framework of their knowledge about them, and would connect them to their actions. Such peculiarities still exist in languages and traditions, as well as in the oral and written speech of nations and peoples over the course of time. Vocabulary created in each language represents a national-cultural wealth belonging to that particular nation, and people find themselves reflected in it. For instance, words and word combinations derived from the relationship human beings establish with the natural environment take up a large amount of room in Uzbek-Spanish dictionaries.

Learning a language other than one's mother tongue corresponds to an endeavour to see the world under another guise. The culture of the country in question is reflected through this world. Learning the word or combination of words of another nation is often tantamount to learning about the world as seen by that nation. This is especially the case where certain phraseological units in one language actively contribute to the understanding of a linguistic picture of the nation. Where the vocabulary of the Uzbek and Spanish languages is concerned, belonging as they do to different systems, an analysis of component expressions of fauna and flora - integral parts of the universe and of natural phenomena

${ }^{2}$ Harris, R., Holmes, H., \& Mertens, D. (2009). Research Ethics in Sign Language Communities. Sign Language Studies, 9(2), 104-131. Retrieved from http://www.jstor.org/stable/26190667 'human', however, in a connotative aspect. People understand justifications for the many ethical prescriptions and

- enriches the subject of linguo-cultural and axiological studies. The evaluation as a discipline has emphasized the importance of critically examining valuing as a component of systematic inquiry, the development of methodological approaches that prioritize stakebolder involvement, and use of criteria to judge quality that include utility, feasibility, and propriety (p.1.).

A negative evaluation is implied by the expression «(ser) un pez gordo (to be a fat fish)» in Spanish. It is generally used in respect of a person of high standing, or a person under the strong protection of some other person, and who may be carrying out an activity contravening the law $\rightarrow$ persona poderosa/influyente/rica $\leftarrow$ powerful/noble/rich person (DRAE, TII, 569). For example: <Persona muy importante y rica, generalmente un político o un narcotraficante: una fiesta llena de peces gordos $^{3}>$. According to the sources, even law-enforcement officers use this expression when they arrest some apprehended criminal ${ }^{4}$. It can therefore be argued that this expression is conceptualized through situations of every-day life, i.e. transferring fishing terms to describe people's actions. Firstly, big fish eat small fish: when this fact is applied to Man's activities, the pejorative sense derives from its semantics. Secondly, during fishing small fish tend to fall into the net more than big fish do. Small fish usually swim in flock, whereas big fish normally do not, and they seldom fall into the fisherman's net. In the above expression this process forms the association with respect to people. Figuratively, people guilty of insignificant delinquencies more often fall foul of the law, but «the big fish» seldom fall into the «net».

The expression $<$ laqqa baliq to'rga tushdi $>$ ( $<$ catfish fell into the net>) in Uzbek may have a synonymous relationship with the phraseological unit <un pez gordo>in Spanish. For example: <<Uni boshqa ish tashvishga solayotgan edi. Ko'k tugmachani bosib, Bitko'zni topdi: - Laqqa baliq to'rga ilinib turibdi, ishimiz oson ko'chadiganga o'xshaydi. Tezda ko'rishimiz kerak. (He was worried about another matter. Pushing the blue button he found Bitkoz: - The catfish fell into the net, it seems that our problem will be solved easily. Let's see him quickly)>.5 In Uzbekistan the catfish is generally regarded as more of a delicacy than most other fish, with less bones. That is why, when one says <catfish fell into the net>, it refers to a rare event or situation, probably long hoped for. In addition, expressions such as 'shark' and 'the old wolf' in the Uzbek oral language are used for officials who have high-ranking positions.

There is a phrase «nahang baliq (shark)» in the Uzbek 'explanatory' dictionary: 2. ko'chma O'ta yulg'ich, o'zlashtiruvchi. U (Anorxon) nahang, sen laqqa. Raislik muhring bilan birga yutib yuboradi. (I.Rahim. Ixlos.) Nafsi nahang Ashurov hash-pash deguncha kolxozning juda ko 'p pulini kam-ko'stiga sarflab yubordi. Gazetadan (English

$3 \begin{gathered}\text { See diccionario.sensagent.com. Accessed } \\ \text { from<http://diccionario.sensagent.com/pez\%20gordo/es-es/> }\end{gathered}$
${ }^{4}$ Cutting the Cod as a Sign of Power/Funny Spanish Expressions related
to $\quad$ Fish. Ibericalanguages.com. Accessed from
$<$ http://ibericalanguages.com/es/expresiones-relacionadas-con-peces/>
$(12.07 .2016)$.

${ }^{5}$ Tulkin Hayit. Flower of Eternity. Toshkent, 2013, p. 77.

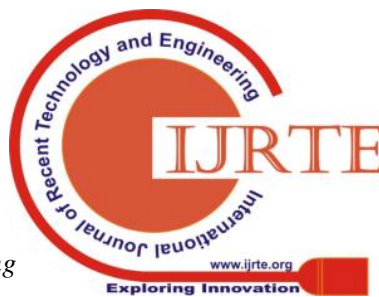


translation: figuratively, the shark, Anorkhon, will swallow you, the catfish, even if you are as much as a provincial governor.) (I. Rakhim. Devotion.) Ashurov, who has a shark's stomach, used a lot of the farm management money for his expenditures, and very rapidly. (EDUL, T III, p.30)). The use of 'shark' points to a negative connotation, since a shark is bigger than a catfish, it is also a rapacious creature, and is moreover capable of swallowing a catfish. Here we are confronted with the laws of Nature: the survival of the fittest! We are dealing here with anthromorphic images, with the more powerful character capable of 'swallowing' another, and the size of a stomach being emphasized. In the following zoomorphic examples, the 'shark' is represented as more powerful, dreadful and adroit in comparison with others, as a synonym of the Spanish expression "el pez gordo", from a semantic and pragmatic point of view: Bu yoqda Arutyunan, Nersesyan, yana allaqancha nahang baliqlar turganida bu itbaliqqa balo bormi? Gobelyan o 'zining «yan»larini ishga solmadimi, demak, «ov» katta emas. (T. Malik. Murdalar gapirmaydilar). English translation: When Arutyunan, Nersesyan and some other sharks are here, what will toads do? Gobelyan did not use his "yan"s, so there's no big 'hunt' on (T. Malik. 'Cadavers do not talk'). We should mention here the fact that the Spanish expression 'pájaro gordo' (fat bird) is also semantically synonymous with 'el pez gordo'. Thus, both languages feature representatives from the world of fish and fishing, applied to people who have gained respect and a high-ranking position in society in the course of their lives. There is a pragmatic sense, however, contradicting national-cultural views and traditions of certain people understood by these expressions. By way of criticism a negative value is implied concerning a certain group of people. From the point of view of an axiological evaluation the following formula may be set out:

Assessing subject $\rightarrow$ anthromorph; evaluated object $\rightarrow$ pez; catfish, shark (zoomorph), assessment $\rightarrow$ person of no benefit to society; result $\rightarrow$ negative feature.

The following lines appear in chapter XX of the famous XI century linguist Yusuf Xos Khojib's novel 'Qutadg'u bilik' «oqqush (Swan)»: <Oqqushdek oqarsa insonning boshi, Dilin oqqush kabi oq qilsin kishi (If a human being's hair whitens as does that of a swan, he should have the pure heart of a swan)>. The white hair of the old man is being compared to the whiteness of the swan and his kindness, honesty and truthfulness are all depicted. Thus, in ancient times the colour white had a similar significance in the Turkic languages, and the whiteness of the swan suggests positive features in people (the word 'swan' translates as «white bird» in Uzbek ). There is no term equivalent to the zoomorph 'swan' in the EDUL dictionary of the Uzbek language : $\angle$ SWAN belongs to the goose family, with white feathers; a water bird with a long neck; sly.> (EDUL,T III, p.183). EDUL contains, however, a proverb with the synonymous zoomorph sly". 'Sly' flies with 'sly', 'goose' moves with 'goose' (EDUL, T V, p. 359). The pragmatics of this proverb argues that even flying birds can differentiate their friends, and so humans must necessarily follow this pattern. T. Malik noted that 'everything in Nature tends to live together with its own kind. Swans don't mix with blackbirds. Though different people appear to be alike, the soul of one can be similar to that of the swan, while the other resembles that of a blackbird'. In this he was comparing the kindness and the unkindness of a human being's soul with a bird's (T. Malik. 2005: 217.) In conclusion the following model was created for the zoomorph 'swan':

Swan $\rightarrow$ whiteness $\rightarrow$ human with kind soul $\rightarrow$ highest (positive) feature of the human

The expression «canto del cisne $\rightarrow$ swan song» is connected with an analogue of zoomorph swan -cisne in Spanishequivalent to 'the last breath, the last word'. The last minutes of a human life correspond to the singing of a swan. Alfred Brem wrote of watching how 'swans were wont to produce something which sounded like 'ship-ship', breaking into song before dying'. This zoological reference is further evidence of the human proximity to Nature. Subsequently, animal behaviour is transferred to human activity. Example: $<$ Curiosamente, las personas poco antes de morir presentan una mejoría extraordinaria, cosa que los médicos que vemos cosas complicadas y que ponen en riesgo la vida, como los intensivistas o los urgenciólogos conocemos como «el canto del cisne» >. In this context, a patient's extraordinary feeling of regained health just prior to his death qualifies, in the words of the doctor, as a 'swan song'. In both languages, especially in fiction, a beautiful image is often portrayed resembling the neck of a swan: in Uzbek: 'Joning bersang, joizdir, bo'yla sifat mahbuba, Hech ko'rmadim aningdek oqqush bo'yin, to'g'ri bo' $y$ ' - the approximate meaning being that the beloved is worth dying for, her angel-like neck recalling the beauty of a swan's neck (Mahtumquli. Bowlike Eyebrows). In Spanish: Evidentemente había que torcerle el cuello al cisne, aunque no lo hubiese mandado Heráclito (J. Cortázar 'Rayuela'). There are numerous instances in folklore not recorded in dictionaries. The Uzbek linguist A. Omonturdiev mentions the fact that questionnaires put to common peasants -but even intelligent people too- mostly receive unsatisfactory replies, in defining the meaning of proverbs connected with the names of livestock (zoonyms). This also applies to the peculiarities of Uzbek phraseology, including the semantics of proverbs and sayings, even though their etymology was included in Uzbek bilingual dictionaries. (Omonturdiyev, 2009: 222). We support this opinion and observation, and consider it reasonable to take into account the meanings of swan expressing whiteness, kindness and most terms such as 'a swan's neck'.

On the whole, then, 'swan' in both languages may be used to express kindness and beauty. Our conclusion follows this formula: assessing subject $\rightarrow$ anthromorph; assessed object $\rightarrow$ cisne; swan (zoomorph), assessing $\rightarrow$ kind soul of the person; result $\rightarrow$ positive feature.

In the course of our research it was observed that the expression 'canto del cisne' was used by people not only in the anthropomorphic sense but also on a universal scale. In the following text stars are said to be unable to fall, while their contact with the atmosphere leaves clear traces as they vanish, this being their 'swan song' in the universe: $<\mathrm{Y}$ (las estrellas) no caen, porque al inflamarse en contacto con la atmósfera, se volatilizan. El trazo brillante que dejan en el cielo es su canto del cisne>. No equivalent terminology 'canto del cisne - swan song' was found in Uzbek.

The Russian linguist, A. G. Nazarian said:

«The role of the hypothesis is also great in the etymology of idioms, whose origin is still unclear. There is a good hypothesis based on the comprehensive accounting of features and on the detailed structural-semantic analysis of 
the considered expression, may shed further light on its origin. When the estimated etymology of an idiom cannot be proved documentarily and supported with examples or facts, it is very important to show its opportunity. It can significantly advance a research of an idiom and bring closer the establishment of its exact etymology» ${ }^{6}$.

Here follow a number of hypotheses concerning the monkey and its significance in both languages: Monkey: this animal is unknown in Uzbekistan. The EDUL dictionary definition for a monkey is as follows: an animal whose trunk and part of its face are covered with hair. In Uzbek: Maymun [a. ق ق 1 baxtli, omadli, maymun] 1 . Tana tuzilishi va qiyofasi odamga o'xshash, sutemizuvchilarning yuksak rivojlangan turkumiga mansub hayvon. Odamsimon maymun. - Eshonoyimning yuzi... maymunning yuziga o'xshagan tirish, badburush ekan. (M. Ismoiliy. Farg'ona t. o.); 2. ko“chma s. t. Badbashara yoki serpardoz odam haqida; Holiga maymunlar yig 'laydi $\rightarrow$ Juda ayanch, og 'ir ahvolga tushdi. O'g 'lingni Mirzakarimakaning ilgarigi toshkentlik kuyovi o'ldirdi, men o'z ko'zim bilan ko'rdim, deyman. Ana undan so'ng xumsaning holiga maymunlar yig 'lasin! A. Qodiriy. O'tgan kunlar (EDUL, T II: 529) (English translation: Monkey[a. ق قد - happy, lucky, monkey] 1. an animal whose trunk and face resemble those of a human being, belonging to the family of highly developed mammalians. - Face of Eshonoyim ... wrinkled and as ugly as a monkey's face. (M. Ismoiliy. Ferghana t.o.); 2 figurative. Concerning an ugly person, or a woman wearing too heavy make-up; monkeys will start crying seeing her condition $\rightarrow$ He was in a very poor and difficult situation. Mirzakarim aka's former son-in-law from Tashkent killed your son, I tell you I saw it with my own eyes. And after this, monkeys will start crying seeing a human being's condition! A. Qodiriy. Days gone by (EDUL, T II, p.529).

We assume this to refer to a state of handsomeness, since in accordance with Arab custom wearing a full beard is one of the signs of beauty. In traditional Arab culture, the length, form and colour of a beard determines the social status of a $\operatorname{man}^{7}$. We consider it necessary to provide an extract described in Zahiruddin Muhammad Babur's (a famous Turkic poet of the XVI century) work in commenting on this proposition: Musavvirlardan Behzod edi, musavvirliq ishini bisyor nozuk qildi. Vale saqolsiz elning chehrasini yomon ochadur. G'abg 'abini ko 'p ulug' tortadur. Saqollik kishini yaxshi chehrakushoyliq qiladir (Boburnoma, 139). English translation: Behzod was one of the painters. He painted extremely delicately, but the faces of beardless people were done badly with too large a double chin. He drew the faces of bearded people quite well (p. 218) ${ }^{8}$. Thus the text gives us to understand that having no beard was one of the signs of ugliness in Uzbeks as well. It is understood from the extract that Kamoliddin Bekhzod depicted the beardless man in some way as ugly as well. In the past such people were called 'ko'sa', 'ko'sanamo' ('beardless', 'looking as if beardless'): $<$ Yoshi yigirma beshlardan oshgan bo 'lsa ham, yuziga hali durust soqol chiqmagan, ko'sanamo Ahmad tanbal og 'zini me'morning qulog 'iga yaqinlashtirib shivirladi (P. Qodirov. Yulduzli tunlar.)> English translation: <Though he is already

\footnotetext{
${ }^{6}$ Назарян А.Г. Почему так говорят по французки. - М., 1968.- 294 с. (Nazarian A.G. Why so speak French?).

${ }^{7}$ Bouhdiba Abdelwahab.Sexuality in Islam. — Routledge, 2013.P.34.

${ }^{8}$ The Baburnama: memoirs of Babur, prince and emperor / trans, Wheeler M. Thackston, Washington, DC, 1996, p. 218.
}

over twenty, there is not enough of a beard on his face, beardless Ahmad Tanbal (lazy bone) whispered in the ears of the sculptor (P. Kadirov. Starry Nights.)>. Beardless Ahmad Tanbal is seen in a comparatively negative light in this extract. He becomes a real man at the age of 25 , with a normal moustache and a beard. From the context it is understood that the writer wishes to give us a negative picture by depicting Ahmad Tanbal in this way.

In Spanish the word "mono/a" - monkey - has two different characteristics: positive and negative. On the one hand, in respect of handsome young boys and women "qué mono/a"; and on the other hand, "como un/a mono/a"; people who imitate others, or somebody else's behaviour, as well as those who drink too much alcohol, are often depicted in expressions where the zoomorph is employed. For example:

1. mono: persona fea. ¡Eres feo como un mono! $\rightarrow$ as ugly as a monkey.

2. mona: mujer guapa. En las expresiones: ¡Qué mona estás! te ves muy mona. $\rightarrow$ expressing beauty and handsomeness.

3. mono: persona que imita a otras. Fulano es un mono, no hace más que imitar a los demás. (O. p.). XLVI.-Adherencia, apego. $\rightarrow$ expressing mimicry or imitation.

4. "dormir la mona" implica entregarse pesadamente al sueño después de una borrachera. $\rightarrow$ falling into a deep sleep after drinking.

5. Aunque la mona se vista de seda, mona se queda (DRAE, ) $\rightarrow$ in Uzbek this coincides with the proverb <qazisan, qartasan, asl zotingga tortasan $>\rightarrow$ English version: $<$ The monkey, even though decorated, is still a monkey>.

Though the origin of the word 'monkey' in both languages is to be found in Arabic, the results of our research show that the variety of meaning is wider in Spanish than in Uzbek. In Uzbek dictionaries, there are no sources that indicate the idea of a monkey's charm in relation to the human being, or any description of human drinking excesses. In assessment, attention was paid to positive and negative features:

a) assessing subject $\rightarrow$ anthromorph, assessed object $\rightarrow$ "mono/a"; monkey (zoomorph), assessment $\rightarrow$ goodlooking, handsome, $\rightarrow$ positive features of human (result) (they exist in Spanish only).

b) assessing subject $\rightarrow$ anthromorph, assessed object $\rightarrow$ "mono/a"; monkey (zoomorph), assessment $\rightarrow$ ugly, not beautiful; imitator; one who likes drinking $\rightarrow$ negative features of human (result) (in Uzbek and Spanish).

\section{CONCLUSION}

A zoomorphism in one language may be interpreted differently in another language. This is reflected in expressions which take into account the national-cultural values of the nations in question. Certain peculiarities attributed to animals are transferred to the actions and character of human beings, with some social phenomena formally connected to the animal. A full description of such expressions is often reflected in folklore, for instance, "Zarbulmasal" of Gulxaniy (Collection of fables or proverbs), or the fables of Aesop, Kalila and Dimna, among others.

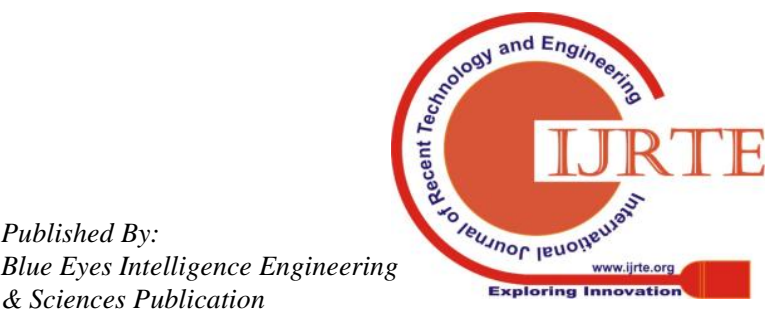


The fact must be underlined that values cannot exist without subject-human feelings, as values cannot be attached to things. This does not, however, mean that values can only be subjective. Their inter-subjective features prove their 'objectivity', which derives from their common ground in the transcendental subject's significance; opinions on assessment are based on objects under assessment.

The 'practical' and 'pragmatic' features of axiology achieve a higher status in such subjects as fundamental philosophy and linguistics, ethno-linguistics, and lingo-cultural studies.

\section{REFERENCES}

1. Bouhdiba, A. (2013). Sexuality in Islam.- Routledge.

2. Bakhronova, D. K. (2015). Zoomorphisms as an object of research in linguo-culturology (Based on the Material of the Spanish Language) The Sixth European Conference on Languages, Literature and Linguistics. "East West" Association, Vienna.

3. Brem, A. (2003). Animal's life. Birds. Two volumes. Volume 1. Moscow: AST

4. Cortázar, J. Rayuela. 'Capítulo 36'. Literaberinto.com Accessed from <http://www.literaberinto.com/cortazar/rayuela36.htm>. (12.07.2019).

5. Diccionario de la Lengua Española de Real Academia Española (1992). Madrid, 21 ed., T. I, II.

6. Estar como pez en el agua hablando español / "Expresiones con peces y pescado". Accessed from $<$ http://ibericalanguages.com/es/expresiones-relacionadas-con-peces/ $>$. (12.07.2019).

7. Moral, R. del (2003). Manual práctico del español coloquial. Editorial Verbum, Madrid.

8. Navoiy, Alisher. "Muhokamatul (1962). lug'atayin".Asarlar.Tashkent.T XIV.

9. Omonturdiev A. J. ( 2009). Euphemics of Professional Speech (Cattle Breeders' Speech). Dissertation, Candidate of Philological Sciences. University of Termez. Tashkent.

10. Sheler, M. (1994). Selected works. Moscow.

11. The Baburnama: Memoirs of Babur, Prince and Emperor / trans. Wheeler M. Thackston(1996), Washington, DC.

12. The Explanatory Dictionary of the Uzbek Language. (2006-2008). T I-V - Toshkent: Uzbek National Encyclopedia Uz.

13. Tokhir, M. (2005). Features of Humanity. (The Book of Behaviour).Tashkent, «Istiqlol». First Edition.

14. Tulkin, H. (2015). Flower of Eternity. Tashkent.

15. Uzbekskie Poslovitsy Pogovorki naBukvu: M. <http://fmc.uz/maqollar.php?page=m>. (10.09.2019)

16. Khojib X.Y. "Qutadg'ubilik". $<$ http://kh-davron.uz/kutubxona/turk/yusuf-xos-hojib-qutadgu-bilik-q adimiy-turkiydan-yangi-tabdil.html>. (10.10.2019)

17. Harris, R., Holmes, H., \& Mertens, D. (2009). Research Ethics in Sign Language Communities. Sign Language Studies, 9(2), 104-131. Retrieved from http://www.jstor.org/stable/26190667 (15.12.2018).

18. Antes si, ahora no; y el día 10, si gano, también. 10 February, 2008. Agnetem.wordpress.com.

Accessedfromhttps://agnetem.wordpress.com/category/elecciones/pag $\mathrm{e} / 3 /$. (08.09.2019).

19. Diccionario Sensagent. Iberica Languages. 2 September, 2014. Accessed from <http://diccionario.sensagent.com/pez\%20gordo/es-es/>.(15.07.2019 ). 